\title{
NOTES
}

\section{THE ART OF WALT WHITMAN'S FRENCH IN "SONG OF MYSELF"}

In 1926, Louise Pound called Walt Whitman's use of foreign languages in his poetry its "most striking feature," classifying his use of French into such categories as political words, military words, musical words, parlor language, literary words, and common expressions. Pound also notes the odd fact that Whitman "nowhere gives reasons for his conspicuous reliance" upon French but speculates that his time in New Orleans and his admiration of French republicanism must have inspired the French in his poetry. ${ }^{1}$ Pound admits, though, that Whitman tends to use French words "for their own sake," sometimes erroneously, sometimes manipulatively. ${ }^{2}$ Gay Wilson Allen enlarges upon this criticism:

[Whitman] is almost childishly fond of foreign words, especially French and Spanish ones, which he sometimes uses with reckless disregard for correct spelling and meaning. ${ }^{3}$

Roger Asselineau, in discussing why Whitman chose not to correct his errors in foreign words even when they were pointed out to him, concludes that "grammatical precision mattered little to him. The sound of these foreign words flattered his ear, which was the only thing that counted."

I have no intention of denying the reasonability of the general critical consensus regarding Whitman's use of French. But I do feel that Whitman may not always be getting full credit for his use of French. Sometimes there is more to his French than the aroma of the glorious Revolution or the affectation of parlor language. In "Song of Myself" Whitman uses two French words that show significant technical sophistication and subtly enrich a major theme in that work. These two words, in fact, are the only two French words in "Song of Myself" which are strictly French words, as opposed to accepted borrowings like rendezvous, embouchures, debouch, or chef d'oeuvres, all of which appear in "Song of Myself." The two French words I will discuss, élèves and accoucheur, are different from the preceding in that they, though common enough in French, are not in the English lexicon or used in English with the assumption that the hearer will understand them. Whitman uses both words as vehicles of multiple suggestion - as puns, in the high poetic tradition.

First let us consider the word élèves, the common French word for pupils or disciples. Whitman uses the word near the end of Section 38 of "Song of Myself." I quote the final six lines of the section (1892 edition):

I troop forth replenish'd with supreme power, one of an average unending procession,

Inland and sea-coast we go, and pass all boundary lines,

Our swift ordinances on their way over the whole earth,

The blossoms we wear in our hats the growth of thousands of years.

Eleves, I salute you! come forward!

Continue your annotations, continue your questionings. 
This might seem at first to be exactly the kind of French usage that Pound, Allen, and Asselineau consider gratuitous or affected. How does eleves, stripped of its italics and accents, improve upon the word students? Students even harmonizes in its alliteration and assonance with other words in the passage. It is true that eleves is somewhat richer than students in its second definition, disciples, touching upon the religious connotations of the passage, but this in itself scarcely justifies the rather rough intrusion of a French word into a poem in English.

More important, I think, is the pun on the etymological root, élever, meaning to raise, semantically far to seek from élève for the average native speaker of French. $L e$ Robert, the comprehensive French dictionary comparable in its authority to the $O x$ ford English Dictionary, states simply that the word comes from the word élever, attested from $1653 .{ }^{5}$ Not one of Le Robert's definitions, citations of special usage, or other attestations of élève makes reference to its etymological root. This loss of semantic relation to their origins is a frequent phenomenon with old and common words in any language: the original metaphor of a word's coinage dies; the new word becomes fully autonomous. What this amounts to for Whitman's use of the word is that eleves suggests raised ones, the word being formed according to the usual rules in French as a substantive from the past participle of élever. Without accents or auditory pronunciation, the two French words are identical. In this case, the students or disciples the speaker addresses would also be seen as an army of raised or resurrected individuals, all of equal stature with himself and each comparable to the glorified Jesus. When the poet-leader who is Whitman himself addresses them with "Eleves, I salute you! come forward!," he echoes Jesus' command at the entrance of Lazarus' tomb, "Lazarus, come forth!" Whitman is enjoining his disciples to come forth into perfected being, not ordinary life. Because all possess "supreme power," each one is "average." These, the deified, are the flowers of evolution, the crown of creation, yet Whitman wittily concludes the section by reminding the resurrected company that they are still students: "Continue your annotations, continue your questionings."

It is worth comparing the 1855 version of this passage with that of the 1892 version to see if the present interpretation of eleves as a sight-pun is substantiated in the original.

I troop forth replenished with supreme power, one of an average unending procession,

We walk the roads of Ohio and Massachusetts and Virginia and Wisconsin and New York and New Orleans and Texas and Montreal and San Francisco and Charleston and Savannah and Mexico,

Inland and by the seacoast and boundary lines. . . . and we pass the boundary lines.

Our swift ordinances are on their way over the whole earth,

The blossoms we wear in our hats are the growth of two thousand years.

Eleves I salute you,

I see the approach of your numberless gangs. . . . I see you understand yourselves and me,

And know that they who have eyes are divine, and the blind and lame are equally divine, 
And that my steps drag behind yours yet go before them,

And are aware how I am with you no more than I am with everybody.

The idea of the eleves as raised ones is even more obvious in this version, as is the idea that the poet is at the same time the divine leader and co-follower (and even the follower of his own disciples). In the 1892 version, Whitman chose to compress the passage considerably by deleting the catalogue of places and by omitting the explicit reference to the blind and the lame. The result is poetry which concentrates its inherent paradoxes; Whitman makes the passage richer and subtler at the risk of losing the reader who will not weigh the full connotations of his words - a risk great poets take freely.

A comparison of the first part of Section 38 in the 1855 and the 1892 editions extends the pattern. The 1855 version is wordier, bringing in more ideas and image patterns. The section begins:

I rise extatic through all, and sweep with the true gravitation, The whirling and whirling is elemental within me.

The 1892 version omits these lines entirely to focus exclusively on the identification of the poet with the suffering, crucified, and then resurrected Jesus.

That I could forget the mockers and insults! . . .

That I could look with a separate look at my own crucifixion and bloody crowning. ...

The grave of rock multiplies what has been confided to it, or to any graves,

Corpses rise, gashes heal, fastenings roll from me.

I troop forth. ...

In short, the 1892 version of the whole section deletes all images and ideas which are not closely related to the messianic theme, resulting in the greater power of the final version.

The second French word in "Song of Myself," accoucheur, employed in the famous apostrophe to Death in Section 49, is closely connected to the foregoing discussion of eleves. Again Whitman puns, letting the word have its dictionary meaning as well as a second meaning related to the etymological root of the word. An accoucheur is a midwife or obstetrician, obviously derived from accoucher, meaning to put to bed. Both ideas are clearly present in the passage, which begins the section.

And as to you Death, and you bitter hug of mortality, it is idle to try to alarm me.

To his work without flinching the accoucheur comes, I see the elder-hand pressing receiving supporting, I recline by the sills of the exquisite flexible doors, And mark the outlet, and mark the relief and escape.

Here Whitman's French pun helps to develop his idea that although death lays us low it is for the sole purpose of regeneration. Death becomes the passage through 
the "flexible doors" of the birth canal to a better incarnation, a "transfer" and a "promotion" to a more perfect state of being.

The birth imagery here picks up a submerged idea in Section 38 as well, in which the poet refers to his "crucifixion and bloody crowning." Jesus's crowning with thorns preceded his crucifixion. Whitman reverses the order because he wishes to allude to the "bloody crowning" of his new birth as well as his identification with Jesus's sufferings.

Both of the French words in "Song of Myself" intensify Whitman's simultaneous opposition and conflation of life and death. The concept is fully mystical, one of Whitman's major themes in all his poetry. In the passages of "Song of Myself" just examined, Whitman sees himself as messianic in his leadership of humanity into a new age. His use of French in those passages proves him Adamic in his creative control of language. As a logical extension of his organic theory of words, Whitman boldly appropriates into English from French two words which compress and enrich his meaning. In his use of foreign words as well as English, Whitman is a follower of Emerson, who urged the poet to mine language wherever he finds it, minting and bringing new words into the currency of the American vernacular. This is not to suggest that Whitman is universally successful in achieving his intentions in the use of foreign words in his poetry - usually he is not-but perhaps some of those words deserve a second look.

Gustavus Adolphus College

DOUGLAS LeONARD

\section{NOTES}

1 Louise Pound, "Walt Whitman and the French Language," American Speech, 1 (May 1926), 421.

2 Pound, p. 423.

3 Gay Wilson Allen, The New Walt Whitman Handbook (New York: New York University Press, 1975), p. 243.

4 Roger Asselineau, The Evolution of Walt Whitman (Cambridge: Harvard University Press, 1962), 2:236.

5 Le Robert Dictionnaire Alphabétique et Analoguique de la Lingua Française (Paris: Société du Nouveau Littré Le Robert, 1973).

\section{THE ENDING OF THE 1855 VERSION OF "SONG OF MYSELF"}

There has been much comment on Whitman's verse structure in Leaves of Grass. Chiefly he focused on the biblical principle of parallelism, where the line is the unit, with the second line either balancing the first, "completing or supplementing its meaning." 1 Put another way, "The law of his structure is that the unit of sense is the measure of the line. The lines, in sense, are end-stopped. Whitman employed everywhere a system of punctuation to indicate his structure. Look down any page of Leaves of Grass, and you will find almost every line ending in a comma; you will find a period at the end of a group of lines or a whole poem." In short, "a run-on line is rare in Whitman-so rare that it may be considered 'a slip."'2 